\title{
Charade of grief
}

- Cite as: CMAJ 2019 September 9;191:E1007. doi: 10.1503/cmaj.190532

"A real experience of death isolates one absolutely. The bereaved cannot communicate with the unbereaved." (Iris Murdoch, An Accidental Man, Chatto \& Windus, 1971)

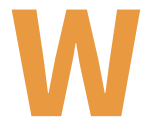

hen my wife died at 52 years of age, I retreated into widowed solitude. I could not think logically; I wandered aimlessly. It was like everything was covered in a thick dust that stuck to the eye of my heart, a heart torn to its barest fibrils. I did not care if I lived or died.

In the first days, I was told by concerned and well-meaning friends to call if I needed anything. Their offers seemed sincere. Yet, weeks later, when I poked one foot from the stupor of grief and asked for a visit, the responses were often ones of deferral. It seemed few wanted to welcome my grief into conversation. "I'm sorry Paul, I'll be away that day. How about another time?" "Oh gosh, my mother is sick, I can't get away right now." "I'm out of town. Sorry." "I'm working a double shift that day. Next week?" Or the simplistic, but most hurtful, "I'll take a rain check if that's okay. I have some things I gotta get done." A rain check for grief. Thoughtless and cutting. My friends' absences tended to be ones of detached self-salvation. It was important for them to feel comfort, not me.

However, when someone did visit and few did - they usually aggravated my grief. Their attempts at conversation were embarrassing and awkward, their words careless and insensitive. "At least she's not suffering anymore." "You look bad. Are you taking care of yourself?" "She's in a better place." "You have your memories." "It'll take time, but you'll find someone to love again." The latter three grated like a hinge needing oil. What better place is there for a mother than with her children? So, do not tell me she is in a better place. And yes, I have memories, but memories are not sol-

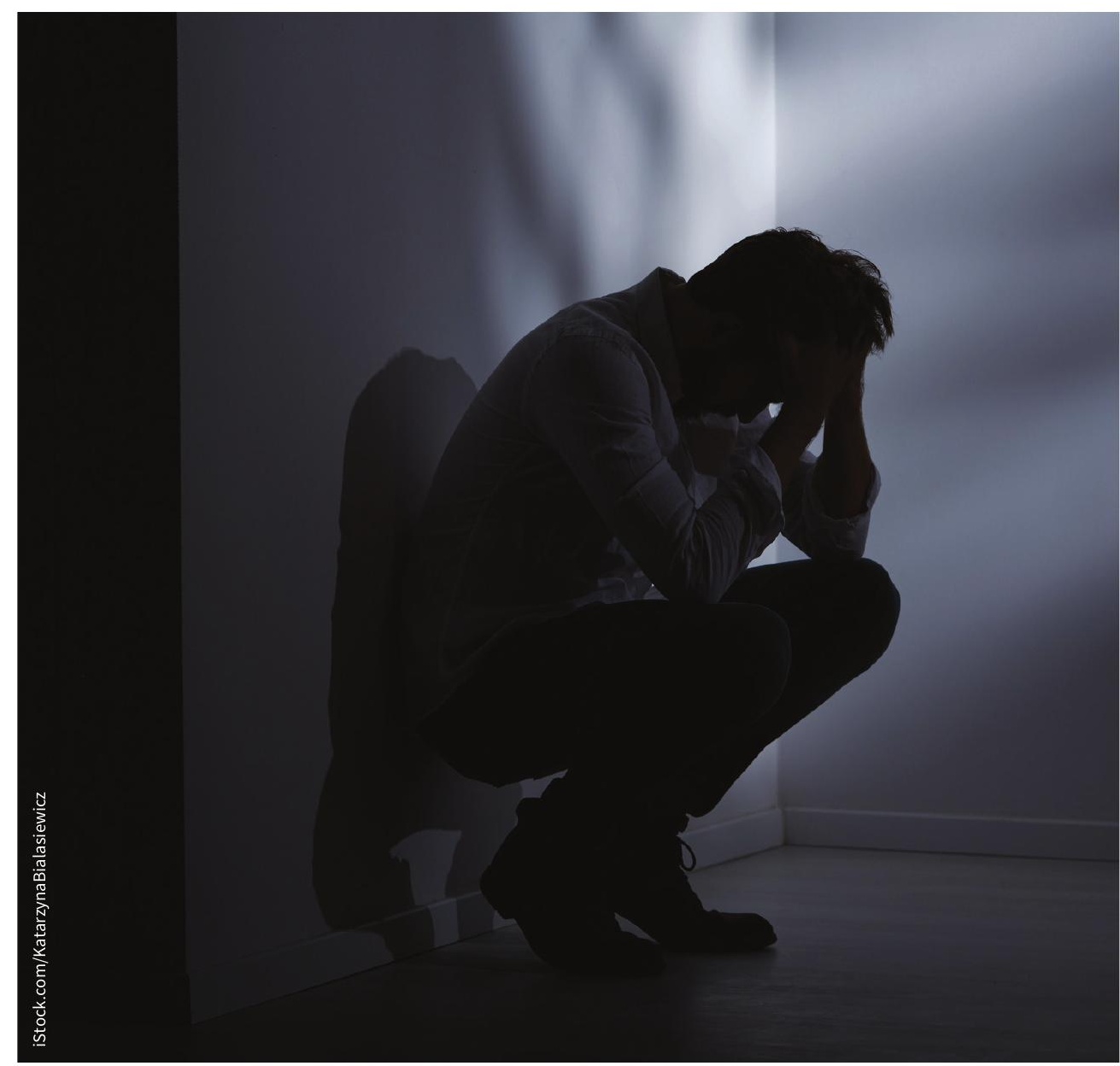

ace, they are what was, not what is or what can be. And I will find someone to love again? Her ashes barely cooled, and I am counselled that I will find someone to love. Just the thought of forging a new life exhausted me, let alone a new relationship.

Still, I knew their intent was one of hope and help; nevertheless, they left me sad and hollow. What I wanted and, more importantly, what I needed, was someone to sit and listen, to offer their presence. I told them there was no need to speak, that I might not speak. But listening is uncomfortable, and sitting in silence even more uncomfortable. We always feel a need for words. And when we are unsure of the words, we shun the encounter. We hibernate from the discomfort.

So, as the days and weeks widened, I began a charade of grief, my responses to "How are you?" worded to comfort oththere." "I'm well." I followed with a smile. Eventually, their ineptness dwindled like ripples in a pond. Most never asked again.

\section{Paul Rousseau MD}

Palliative Care, Charleston, SC

This article has been peer reviewed. ers. "I'm doing okay." "I'm hanging in 